\title{
Anticancer effect of Sargassum oligocystom hydroalcoholic extract against SW742, HT-29, WiDr and CT-26 colorectal cancer cell lines and expression of P53 and APC genes
}

\section{Esraa Ghazy ( $D$ esraa.ghazi2021@gmail.com )}

University of Baghdad

Adil G. Fadil

Basrah Medical College

Bashdar Mahmud Hussen

Hawler Medical University

Ali H. Al-Marzoqi

Hillel Yaffe Medical Center

\section{Research Article}

Keywords: Colorectal cancer, cell lines, Sargassum oligocystom, apoptosis

Posted Date: September 20th, 2021

DOI: https://doi.org/10.21203/rs.3.rs-906543/v1

License: (c) (i) This work is licensed under a Creative Commons Attribution 4.0 International License. Read Full License

Version of Record: A version of this preprint was published at Journal of Gastrointestinal Cancer on January 9th, 2022. See the published version at https://doi.org/10.1007/s12029-021-00765-0. 


\section{Abstract \\ Background}

Colorectal cancer (CRC) is the third most common cancer in the world, with enhancing morbidity and mortality each year. Due to the drug resistance against CRC, the use of novel compounds besides chemotherapy is required. Natural seafood contains large amounts of biologically active substances with new chemical structures and new medicinal activities. The aim of this study was to evaluate the effects of hydroalcoholic extract of Sargassum oligocystom algae on SW742, HT-29, WiDr and CT-26 CRC cell lines and to evaluate the expression of P53 and APC genes using quantitative real time PCR (RT-qPCR).

\section{Methods}

The cytotoxicity of $S$. oligocystom hydroalcoholic extract was determined by MTT and trypan blue methods in six different concentrations including $0.1,0.2,0.5,1,2$ and $4 \mathrm{mg} / \mathrm{mL}$ on various $\mathrm{CRC}$ cell lines and a control group. The expression of P53 and APC genes in exposure to $2 \mathrm{mg} / \mathrm{mL}$ of the extract was also evaluated using RT-qPCR.

\section{Results}

The LD50 and LD90 of S. oligocystom included 0.5-1 and $>2 \mathrm{mg} / \mathrm{mL}$, respectively mostly affecting SW742 and CT-26 cells. In the trypan blue test, $90 \%$ viability and death of cells was observed at 0.1 and $4 \mathrm{mg} / \mathrm{mL}$ of extract, respectively. The $2 \mathrm{mg} / \mathrm{mL}$ was a safe cytotoxic concentration. A significant viability decrease was observed at concentrations $\geq 1 \mathrm{mg} / \mathrm{mL}$ ( $p<0.001$ ). S. oligocystom extract at $2 \mathrm{mg} / \mathrm{mL}$ significantly increased the expression of APC being 2.2 fold $(p<0.001)$ but not P53 gene to be 0.66 fold $(p=0.323)$ after $24 \mathrm{~h}$.

\section{Conclusion}

These results indicated that the brown algae $S$. oligocystom extract had significant antitumor effects against the SW742, HT-29, WiDr and CT-26 CRC cell lines and especially CT-26, suggesting that it may be a potential candidate for further studies and therefore designing drugs of natural anti-cancer origin. The S. oligocystom had anticancer effect via increase in the APC gene expression.

\section{Introduction}

One of the most common problems in the medical world has been the resistance of cancer cells to antitumor drugs, hence finding novel anti-cancer compounds with minimal side effects seems necessary with this regard. Colorectal cancer (CRC) mainly originates from adenomatous polyps, some of which are premalignant and develop into cancer [1,2]. CRC generally occurs among people $>50$ years of age and older 
when abnormal cells divide in the large intestinal epithelium. The mortality rate from CRC is about $40 \%$. Genetic factors and inflammation of colon epithelial cells, epigenetics, and individual behavior and nutrition are important in the onset and progression of CRC [3, 4]. Approximately $30 \%$ of cases are inherited and people who consume more calories, protein and fat are at greater risk. The apoptosis in cancer cells inhibits cancer progression $[5,6]$. The development of anticancer drug resistance is also a dilemma. Anticancer drugs should act exclusively on cancer cells, while some of the chemotherapy drugs currently used in cancer patients have many side effects on the human body $[7,8]$. These effects include bleeding, hair loss, diarrhea, and device suppression, so research is needed to find a compound with especial targeting. Antitumor properties that have the ability to prevent the spread and growth of cancer cells have made significant progress in recent years due to the vital biological role of seaweed in the safety and improvement of life of cancer patients [7, 8]. Extensive studies in medical-industrial applications of these products have been developed and their anti-tumor effects have led to the pursuit of wider studies by researchers. The cytotoxic effects of extracts of some green and brown algae in a dosedependent response against leukemia in mice were subsequently studied, assessing the effect of Spirulina blue algae polysaccharide inhibitory effects against several tumors [10,11]. The cytotoxic effects of red seaweed Sargassum crispum and Sargassum oligocystom has revealed promising results when determined with IC50 in vitro [12-14]. The apoptotic effects of brown algae have also been confirmed by microscopic observations and analytical methods by MTT assay and enzyme-linked immunosorbent assay (ELISA). Bioactive compounds that induce apoptosis in cancer cells can be considered as an effective therapeutic agent. Aqueous algae compounds mostly include polysaccharides, flortanins, carotenoids, minerals, peptides and sulfo-peptides [10, 11]. Among brown algae, Sargassum spp. contain a glycoprotein with anti-cancer effects against the human CRC $[13,14]$. The anticancer effects of several algal genera, particularly Sargassum spp against human leukemia cells (MOLT), K562, mouse lymphocytic leukemia cells (p.388), 180-sarcoma cells have been revealed. Our aim was assessment of anticancer effect of S. oligocystom hydroalcoholic extract against SW742, HT-29, WiDr and CT-26 CRC cell lines and expression of P53 and APC genes.

\section{Materials And Methods}

\section{Algae collection and extract preparation}

S. oligocystom was collected from the Persian Gulf. After washing the algae, it was dried at room temperature for two weeks and after cleaning the obtained fine powder, it was combined with $300 \mathrm{~mL}$ of deionized water and the obtained suspension was boiled for 3 hours and then the suspension was passed through paper. The filtered hydroalcoholic extract was lyophilized into the powder and stored at $4^{\circ} \mathrm{C}$ until use [15].

\section{Preparation and culture of cell lines}

Various CRC cell lines including SW742, HT-29, WiDr and CT-26 cells were purchased from Pasteur Institute of Iran. The cell lines were placed in DMEM medium with $10 \%$ fetal bovine serum (FBS) and 100 
$\mu \mathrm{g} / \mathrm{mL}$ of penicillin and streptomycin and incubated at $37^{\circ} \mathrm{C}$ containing $5 \% \mathrm{CO} 2$ and $90 \%$ of humidity.

\section{Preparation of the algae extract}

Firstly, $100 \mathrm{mg}$ of lyophilized $S$. oligocystom powder was weighed and $1 \mathrm{~mL}$ of phosphate buffered saline (PBS) was added to the powder, and after vortex, $9 \mathrm{~mL}$ of medium was added and extract was reached to a volume of $10 \mathrm{~mL}$ and then filtered using a $0.2 \mu \mathrm{L}$ filter and completely purified and homogenized. The prepared extract was stored at $-20^{\circ} \mathrm{C}$ until use $[15,16]$.

\section{The MTT assay}

In this method, cells $(100 \mu \mathrm{L})$ were cultured in 96-well plates. Then, concentrations $0.1,0.2,0.5,1,2$ and $4 \mathrm{mg} / \mathrm{mL}$ of the extract were prepared and each concentration was exposed to each 96-well plate containing each cell line as an independent group. The plates were incubated in 5\% CO2 and 90\% humidity for 24 and 48 hrs separately. Then each supernatant was taken and MTT dye was added to wells and the plates were wrapped in aluminum foil and incubated for 4 hours. Then the MTT dye was taken and DMSO was added to each well and placed in the shaker for 20 minutes to make it completely uniform and then light absorbance rate of each well was measured at $570 \mathrm{~nm}$ wavelength $[16,17]$.

\section{Cells viability using trypan blue dye}

Briefly, the cells were cultured in 96-well plates containing the DMEM medium and various concentrations of S. oligocystom was added and incubated for $72 \mathrm{~h}$ at $37^{\circ} \mathrm{C}$ and supplementation of $5 \% \mathrm{CO} 2$. Next $20 \mu \mathrm{L}$ of trypan blue was mixed with $20 \mu \mathrm{L}$ of culture cell and the number of cells were counted using hemocytometer neobar lamella. The percentage of living cells was measure using the following formula:

Cells viability percentage $=1-($ living cells $/$ total cells $) \times 100$

\section{Expression of APC and P53 genes}

The cell lines were exposed to $2 \mathrm{mg} / \mathrm{mL}$ of $S$. oligocystom for $24 \mathrm{~h}$. Next, RNA extraction from each cell line was conducted using Gen-All kit according to protocol of the manufacturer. The real-time PCR reaction was performed at a final volume of $20 \lambda$ and repeated twice for each group. The concentration of primers was $150 \mathrm{nM}$. The quantification and analysis of gene expression was performed using semiquantitative method considering $\triangle \triangle C T$ formula and RealTime PCR ABI software [].

\section{Data analysis}

Results analysis was performed using SPSS software version 21 and One-way ANOVA statistical test. Quantity difference was defined at level of 0.05 .

\section{Results}

\section{MTT assay}


The 50\% cell cytotoxicity (LD50) of S. oligocystom against SW742, HT-29, WiDr and CT-26 cell lines after $24 \mathrm{~h}$ included $0.5,1,1$ and $0.5 \mathrm{mg} / \mathrm{mL}$, respectively (figure 1 ). After $48 \mathrm{~h}$, the LD50 of this algae included 0.2 , $0.5,0.5$ and $0.2 \mathrm{mg} / \mathrm{mL}$, respectively. Moreover, $L D 90$ of this algae was $>2 \mathrm{mg} / \mathrm{mL}$ after $24 \mathrm{~h}$ and $>1 \mathrm{mg} / \mathrm{mL}$ after $48 \mathrm{~h}$ for all cell lines. The results exhibited that concentration of $\geq 0.5 \mathrm{mg} / \mathrm{mL}$ of $S$. oligocystom can be considered for anticancer therapies.

According to the MTT assay, S. oligocystom exerted a substantial anticancer effect at $4 \mathrm{mg} / \mathrm{mL}$, however, this concentration was also toxic against normal cells. Therefore, the concentration of $2 \mathrm{mg} / \mathrm{mL}$ was efficient against all cell lines. Moreover, these effects were time-dependent.

\section{Trypan blue test}

In the concentration of $4 \mathrm{mg} / \mathrm{mL}$ of $S$. oligocystom, $96 \%$ of cells were killed, and at concentrations 2,1 , $0.5,0.2$ and $0.1 \mathrm{mg} / \mathrm{mL} 91 \%, 81 \%, 56 \%, 31$ and $11 \%$ of them were killed, respectively (table 1 ). There was no significant difference among various cell lines, but a significant viability decrease was observed at concentrations $\geq 1 \mathrm{mg} / \mathrm{mL}$.

Table1. The trypan blue test and the viability percentage of cells

\begin{tabular}{|lllll|}
\hline S. oligocystom Co. & SW742 & HT-29 & WiDr & CT-26 \\
\hline $4 \mathrm{mg} / \mathrm{mL}$ & 4 & 5 & 4 & 3 \\
\hline $2 \mathrm{mg} / \mathrm{mL}$ & 9 & 10 & 9 & 8 \\
\hline $\mathbf{m g} / \mathrm{mL}$ & 19 & 20 & 20 & 18 \\
\hline $0.5 \mathrm{mg} / \mathrm{mL}$ & 54 & 55 & 54 & 53 \\
\hline $0.2 \mathrm{mg} / \mathrm{mL}$ & 70 & 69 & 68 & 67 \\
\hline $0.1 \mathrm{mg} / \mathrm{mL}$ & 89 & 88 & 89 & 87 \\
\hline
\end{tabular}

\section{Gene expression}

The effect of $2 \mathrm{mg} / \mathrm{mL}$ of $S$. oligocystom on the expression of APC and P53 genes after $24 \mathrm{~h}$ included 2.2 fold $(p<0.001)$ increase in the former and 0.66 fold $(p=0.323)$ increase in the latter genes. Therefore, the $S$. oligocystom had anticancer effect via increase in the APC gene.

\section{Discussion}

The cancer has an increasing trend around the world. Physicians and researchers have been trying to improve the general condition of cancer patients using different methods of chemotherapy, radiation therapy and surgery [1-3]. However, despite the development of therapeutic interventions, development of 
novel chemotherapeutics, the mortality rate of patients with CRC is still high [18]. Therefore, the application of novel alternative compounds in various extracts will be promising for inducing cell death (apoptosis) in cancer cells. It has been shown that hydroalcoholic extract of some algal species had significantly higher anticancer effects than other extracts against cancer cells [19-21]. In another study, alcoholic and chloroform extracts of Polysiphonia lanosa were significantly more effective against DLD-1 and HTC-116 CRC cell lines [22]. Moreover, Gracilaria edulis methanolic extract had significantly higher effect against HT-29 CRC cells [23].

In this study, the effect of hydroalcoholic extract of $S$. oligocystom was evaluated against several CRC cell lines. The $50 \%$ cell cytotoxicity (LD50) of S. oligocystom against SW742, HT-29, WiDr and CT-26 cell lines after $24 \mathrm{~h}$ included $0.5,1,1$ and $0.5 \mathrm{mg} / \mathrm{mL}$, respectively (Fig. 1). After $48 \mathrm{~h}$, the LD50 of this algae included $0.2,0.5,0.5$ and $0.2 \mathrm{mg} / \mathrm{mL}$, respectively. Moreover, LD 90 of this algae was $>2 \mathrm{mg} / \mathrm{mL}$ after $24 \mathrm{~h}$ and $>1 \mathrm{mg} / \mathrm{mL}$ after $48 \mathrm{~h}$ for all cell lines. The results exhibited that concentration of $\geq 0.5 \mathrm{mg} / \mathrm{mL}$ of $S$. oligocystom can be considered for anticancer therapies. It has been verified that Sargassum spp have antioxidant and anticancer effects against some cancer cell lines such as HepG2, Hela, MDA-MB-231, MCF-7, HT-29 and LNCap in vitro. We also did not assess the in vivo results. In previous studies, Sargassum spp has conferred anticancer effects at higher concentrations [21-26].

In the trypan blue test, in the concentration of $4 \mathrm{mg} / \mathrm{mL}$ of $S$. oligocystom, a mean of $96 \%$ of cells were killed, and at concentrations $2,1,0.5,0.2$ and $0.1 \mathrm{mg} / \mathrm{mL}, 91 \%, 81 \%, 56 \%, 31$ and $11 \%$ of them were killed, respectively. There was no significant difference among various cell lines, but a significant viability decrease was observed at concentrations $\geq 1 \mathrm{mg} / \mathrm{mL}$. It is crucial to determine a special dose for anticancer treatment using more exact verification of anticancer effects of $S$. oligocystom because of potential effects in this study.

We also observed that $S$. oligocystom can increased the expression of APC gene, a regulatory gene necessary for the control of cell division. One of the most common mutations in the CRC development includes the inactivation of the APC gene which results in uncontrolled cells proliferation and polyp development. However, patients with APC mutations have the risk of developing CRC approximately at the age of 40 [27]. The APC protein from mutation is truncated, abnormal, and dysfunctional. This short protein cannot prevent cell overgrowth, thus leading to the formation of polyps that can become cancerous. APC is also involved in the demonstration of microtubules by binding to the PD2 domain. APC inactivation can be initiated after specific chain reactions in the cytoplasm [28]. Mutations in the APC gene mostly occur early in cancers, such as CRC. Human develop the CRC due to mutations in the APC gene.

In addition, P53 acts as a guardian of the genome to maintain genome stability by preventing incidence of mutations. This suggests that the TP53 gene plays an important role in preventing cancer formation, with proteins encoded by TP53 binding to DNA and regulating gene expression to prevent genome mutation (in normal cells P53 binds to its negative regulator, MDM2 complex). Following DNA damage or 
other stresses, different pathways lead to the dissociation of P53 and the MDM2 complex. P53 activation causes the cell cycle arrest and allows cell repair or apoptosis $[29,30]$.

\section{Conclusion}

Herein, S. oligocystom was firstly studied to effect on SW742, HT-29, WiDr and CT-26 CRC cell lines and it was confirmed that the algae hydroalcoholic extract conferred toxic activity and growth inhibition against CRC cells. Gene expression analysis exhibited cell death inducing by the extract of the S. oligocystom through activating and increasing the expression of the APC gene, which is a tumor suppressor gene, especially in CRC cells. According to our results, S. oligocystom exerted a substantial anticancer effect at $4 \mathrm{mg} / \mathrm{mL}$, however, this concentration was also toxic against normal cells. Therefore, the concentration of $2 \mathrm{mg} / \mathrm{mL}$ was safe and efficient against all cell lines. Moreover, these effects were time-dependent.

\section{Declarations}

\section{Funding}

This study was supported by Baghdad University.

Conflicts of interest/Competing interests (include appropriate disclosures)

None to declare

\section{Ethics approval}

This study was supported by Baghdad University.

\section{Consent to participate}

Not applicable

\section{Consent for publication}

The authors have the consent to submit and publish the manuscript in the journal.

\section{Availability of data and material}

Not applicable

Code availability (software application or custom code)

Not applicable

\section{References}


1. Kim EJ, Park SY, Lee JY, Park JH. Fucoidan present in brown algae induces apoptosis of human colon cancer cells. BMC Gastroenterol. 2010;10:96.

2. Siegel R, Naishadham D, Jemal A. Cancer statistics. CA Cancer J Clin. 2012;62:10-29.

3. Perez EA. Impact, mechanisms, and novel chemotherapy strategies for overcoming resistance to anthracyclines and taxanes in metastatic breast cancer. Breast Cancer Res Treat. 2009;114(2):195201.

4. Kranz D, Dobbelstein M. A killer promoting survival: p53 as a selective means to avoid side effects of chemotherapy. Cell Cycle. 2012;11(11):2053-4.

5. Athukorala Y, Kim KN, Jeon YJ. Antiproliferative and antioxidant properties of an enzymatic hydrolysate from brown alga, Ecklonia cava. Food Chem Toxicol. 2006;44(7):1065-74.

6. - Turner JP, Shakib S, Singhal N, Hogan-Doran J, Prowse R, Johns S, Bell JS. Prevalence and factors associated with polypharmacy in older people with cancer. Support Care Cancer. 2014 Jul;22(7):1727-34.

7. Ghosh S. Cisplatin: The first metal based anticancer drug. Bioorganic chemistry. 2019;88:102925.

8. Martin AC, Tomasin R, Luna-Dulcey L, Graminha AE, Naves MA, Teles RH, da Silva VD, da Silva JA, Vieira PC, Annabi B, Cominetti MR. [10]-Gingerol improves doxorubicin anticancer activity and decreases its side effects in triple negative breast cancer models. Cell Oncol. 2020 Oct;43(5):915-29.

9. Sanjeewa KA, Lee JS, Kim WS, Jeon YJ. The potential of brown-algae polysaccharides for the development of anticancer agents: An update on anticancer effects reported for fucoidan and laminaran. Carbohydrate polymers. 2017 Dec;1:177:451-9.

10. Lefranc F, Koutsaviti A, loannou E, Kornienko A, Roussis V, Kiss R, Newman D. Algae metabolites: From in vitro growth inhibitory effects to promising anticancer activity. Natural product reports. 2019;36(5):810-41.

11. Haq SH, Al-Ruwaished G, Al-Mutlaq MA, Naji SA, Al-Mogren M, Al-Rashed S, Ain QT, Al-Amro AA, AlMussallam A. Antioxidant, anticancer activity and phytochemical analysis of green algae, Chaetomorpha collected from the Arabian Gulf. Scientific reports. 2019 Dec 11;9(1):1-7.

12. Pugazhendhi A, Prabhu R, Muruganantham K, Shanmuganathan R, Natarajan S. Anticancer, antimicrobial and photocatalytic activities of green synthesized magnesium oxide nanoparticles (MgONPs) using aqueous extract of Sargassum wightii. Journal of Photochemistry and Photobiology B: Biology. 2019 Jan 1;190:86-97.

13. Surits VV, Usoltseva RV, Shevchenko NM, Thinh PD, Ermakova SP. Structural characteristics and anticancer activity in vitro of fucoidans from brown seaweeds Sargassum miyabei and S. oligocystum. Chemistry of Natural Compounds. 2020 Jan;56(1):34-8.

14. Ranahewa $T H$, Premarathna $A D$, Wijesundara RM, Wijewardana V, Jayasooriya AP, Rajapakse RP. Biochemical composition and anticancer effect of different seaweed species (In-vitro and in-vivo studies). Sustain. MAr. Struct.. 2019;2.

15. Lim S, Cheung P, Ooi V, Ang P. Evaluation of antioxidative activity of extracts from a brown seaweed Sargassum siliquastrum. J Agric Food Chem. 2002;50(13):3862-6. 
16. Li Y, Huang W, Huang S, Du J, Huang C. Screening of anti-cancer agent using zebrafish: Comparison with the MTT assay. Biochem Biophys Research Communication. 2012;422(1):85-90.

17. Nath M, Vats M, Roy P. Tri- and diorganotin (IV) complexes of biologically important orotic acid synthesis, spectroscopic studies, in vitro anticancer, DNA fragmentation, enzyme assays and in vivo anti-inflammatory activities. Europ J Medical Chem. 2012;59:310-21.

18. Grasselli J, Elez E, Caratù G, Matito J, Santos C, Macarulla T, Vidal J, Garcia M, Viéitez JM, Paéz D, Falcó E. Concordance of blood-and tumor-based detection of RAS mutations to guide anti-EGFR therapy in metastatic colorectal cancer. Ann Oncol. 2017;28(6):1294-301.

19. Kiadaliri M, Firouzbakhsh F, Deldar H. Effects of feeding with red algae (Laurencia caspica) hydroalcoholic extract on antioxidant defense, immune responses, and immune gene expression of kidney in rainbow trout (Oncorhynchus mykiss) infected with Aeromonas hydrophila. Aquaculture. 2020 Sep;15:526:735361.

20. Movahed A, Ghaderi M, Daneshi A, Nabipour I, Keshavarz M. Hydroalcoholic extract of Sargassum Oligocystum attenuates pentylenetetrazole-induced seizures by potentiating antioxidant activity in mice. International Journal of Epilepsy. 2017 Dec;4(02):159-66.

21. Moshfegh A, Jalali A, Salehzadeh A, Jozani AS. Biological synthesis of silver nanoparticles by cellfree extract of Polysiphonia algae and their anticancer activity against breast cancer MCF-7 cell lines. Micro \& Nano Letters. 2019 May 2;14(5):581-4.

22. Jesus A, Correia-da-Silva M, Afonso C, Pinto M, Cidade H. Isolation and potential biological applications of haloaryl secondary metabolites from macroalgae. Marine drugs. 2019 Feb;17(2):73.

23. Karimzadeh K, Zahmatkesh A. Phytochemical screening, antioxidant potential, and cytotoxic effects of different extracts of red algae (Laurencia snyderiae) on HT29 cells. Research in Pharmaceutical Sciences. 2021 Aug;16(4):400.

24. Pugazhendhi A, Prabhu R, Muruganantham K, Shanmuganathan R, Natarajan S. Anticancer, antimicrobial and photocatalytic activities of green synthesized magnesium oxide nanoparticles (MgONPs) using aqueous extract of Sargassum wightii. Journal of Photochemistry and Photobiology B: Biology. 2019 Jan 1;190:86-97.

25. Palanisamy S, Vinosha M, Manikandakrishnan M, Anjali R, Rajasekar P, Marudhupandi T, Manikandan R, Vaseeharan B, Prabhu NM. Investigation of antioxidant and anticancer potential of fucoidan from Sargassum polycystum. International journal of biological macromolecules. 2018 Sep $1 ; 116: 151-61$.

26. Palanisamy S, Vinosha M, Marudhupandi T, Rajasekar P, Prabhu NM. Isolation of fucoidan from Sargassum polycystum brown algae: Structural characterization, in vitro antioxidant and anticancer activity. International journal of biological macromolecules. 2017 Sep 1;102:405 - 12.

27. Aghabozorgi AS, Bahreyni A, Soleimani A, Bahrami A, Khazaei M, Ferns GA, Avan A, Hassanian SM. Role of adenomatous polyposis coli (APC) gene mutations in the pathogenesis of colorectal cancer; current status and perspectives. Biochimie. 2019 Feb;1:157:64-71. 
28. Zhou X, Jiao D, Dou M, Zhang W, Hua H, Chen J, Li Z, Li L, Han X. Association of APC gene promoter methylation and the risk of gastric cancer: A meta-analysis and bioinformatics study. Medicine. 2020 Apr;99(16).

29. Gupta A, Shah K, Oza MJ, Behl T. Reactivation of p53 gene by MDM2 inhibitors: A novel therapy for cancer treatment. Biomedicine \& Pharmacotherapy. 2019 Jan 1;109:484 - 92.

30. Badr EA, Assar MF, Gohar SF, Badr MH, Hathout RM, El-Kousy SM. The clinical impact of miRNA34a and P53 gene expression in colon cancer. Biochemistry and biophysics reports. 2018 Dec 1;16:8895.

\section{Figures}

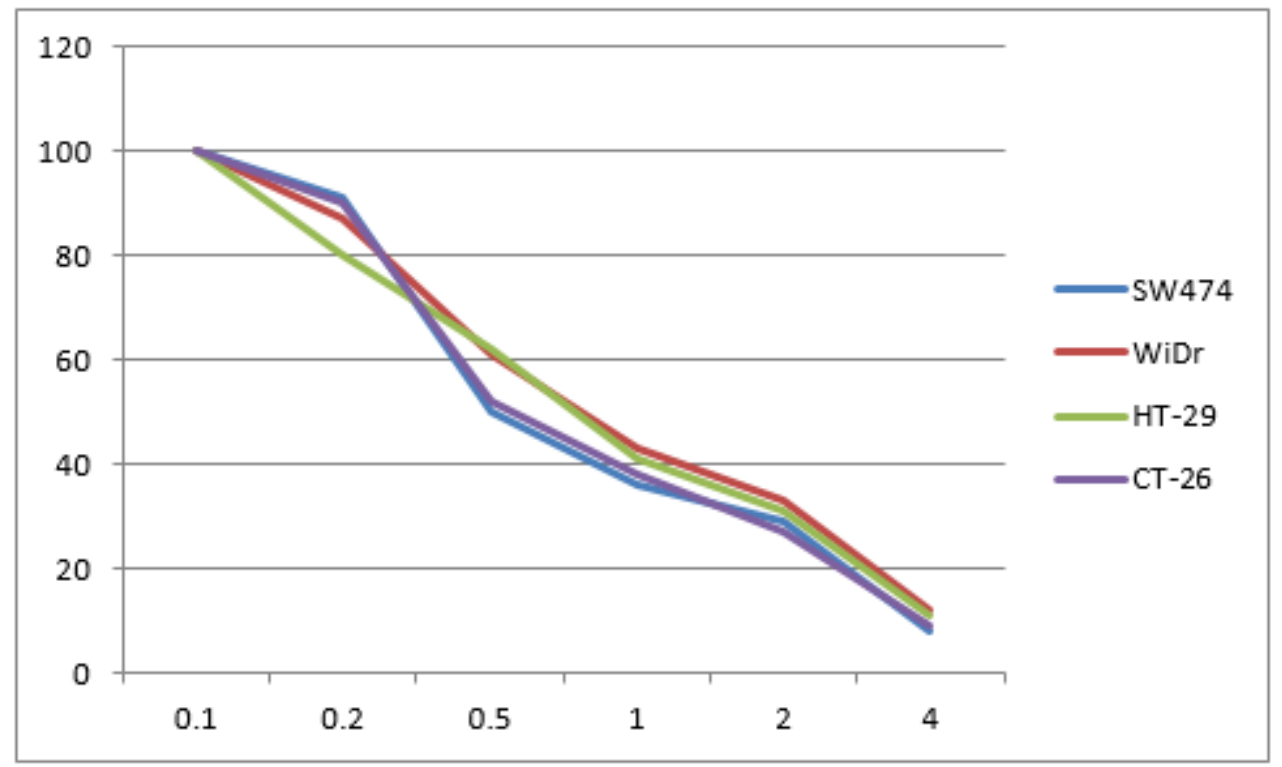

\section{Figure 1}

The MTT assay of the S. oligocystom against SW742, HT-29, WiDr and CT-26 cell lines after 48h (viability percentage) 